\title{
Correction to: Expressions of collective grievance as a feedback in multi-actor adaptation to water risks in Mexico City
}

\author{
Hallie Eakin ${ }^{1} \cdot$ Rebecca Shelton ${ }^{1} \cdot$ Andrés Baeza ${ }^{1} \cdot$ Luis A. Bojórquez-Tapia ${ }^{2} \cdot$ Shalae Flores $^{1} \cdot$ Jagadish Parajuli $^{1}$. \\ lleana Grave ${ }^{2}$. Alejandra Estrada Barón ${ }^{2}$. Bertha Hernández ${ }^{2}$
}

Published online: 24 April 2020

(C) The Author(s) 2020

\section{Correction to: Regional Environmental Change (2020) 20: 17. https://doi.org/10.1007/s10113-020-01588-8}

The article "Expressions of collective grievance as a feedback in multi-actor adaptation to water risks in Mexico City", written by Hallie Eakin, Rebecca Shelton, Andrés Baeza, Luis A. Bojórquez-Tapia, Shalae Flores, Jagadish Parajuli, Ileana Grave, Alejandra Estrada Barón, Bertha Hernández, was originally published electronically on the publisher's internet portal (currently SpringerLink) on March 2020 without open access.

With the author(s)' decision to opt for Open Choice, the copyright of the article changed on Springer-Verlag GmbH Germany, part of Springer Nature 2020 to (C) The Author(s) 2020 and the article is forthwith distributed under the terms of the Creative Commons Attribution 4.0 International License, which permits use, sharing, adaptation, distribution and reproduction in any medium or format, as long as you give appropriate credit to the original author(s) and the source, provide a

The online version of the original article can be found at https://oi.org/ 10.1007/s10113-020-01588-8

Hallie Eakin

hallie.eakin@asu.edu

Rebecca Shelton

rebecca.shelton@asu.edu

Andrés Baeza

abaezaca@asu.edu

Luis A. Bojórquez-Tapia

luis@multicriteria.org

Shalae Flores

cosmicdryfdr@gmail.com

Jagadish Parajuli

jagadish.parajuli@asu.edu link to the Creative Commons license, and indicate if changes were made. The images or other third party material in this article are included in the article's Creative Commons license, unless indicated otherwise in a credit line to the material. If material is not included in the article's Creative Commons license and your intended use is not permitted by statutory regulation or exceeds the permitted use, you will need to obtain permission directly from the copyright holder. To view a copy of this license, visit http://creativecommons.org/licenses/ by/4.0\%.

The original article was corrected.

Open Access This article is licensed under a Creative Commons Attribution 4.0 International License, which permits use, sharing, adaptation, distribution and reproduction in any medium or format, as long as you give appropriate credit to the original author(s) and the source,
Ileana Grave

igrave@iecologia.unam.mx

Alejandra Estrada Barón

ale.esba@gmail.com

Bertha Hernández

berthaha5@gmail.com

1 School of Sustainability, Julie Ann Wrigley Global Institute of Sustainability, Arizona State University, Tempe, AZ, USA

2 Laboratorio Nacional de Ciencias de la Sostentabilidad, Instituto de Ecología, Universidad Nacional Autónoma de México, Mexico City, Mexico 
provide a link to the Creative Commons licence, and indicate if changes were made. The images or other third party material in this article are included in the article's Creative Commons licence, unless indicated otherwise in a credit line to the material. If material is not included in the article's Creative Commons licence and your intended use is not permitted by statutory regulation or exceeds the permitted use, you will need to obtain permission directly from the copyright holder. To view a copy of this licence, visit http://creativecommons.org/licenses/by/4.0/. 